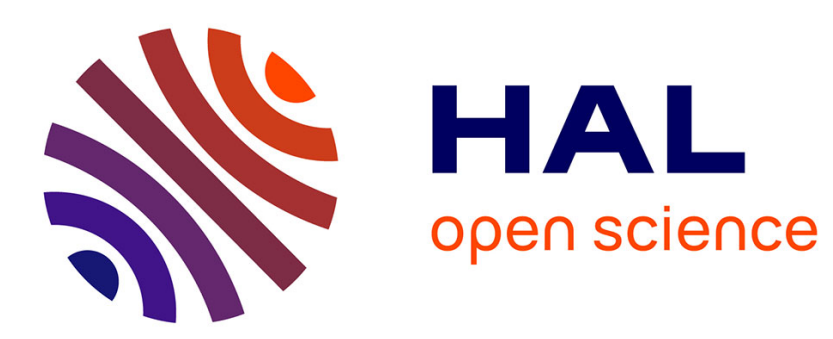

\title{
Outline of a Methodic Realization of Construction Kits for Changeable Production Systems
}

Michael Quade, David Jentsch, Egon Mueller

\section{To cite this version:}

Michael Quade, David Jentsch, Egon Mueller. Outline of a Methodic Realization of Construction Kits for Changeable Production Systems. IFIP International Conference on Advances in Production Management Systems (APMS), Sep 2014, Ajaccio, France. pp.192-199, 10.1007/978-3-662-447338_24. hal-01387180

\author{
HAL Id: hal-01387180 \\ https://hal.inria.fr/hal-01387180
}

Submitted on 25 Oct 2016

HAL is a multi-disciplinary open access archive for the deposit and dissemination of scientific research documents, whether they are published or not. The documents may come from teaching and research institutions in France or abroad, or from public or private research centers.
L'archive ouverte pluridisciplinaire HAL, est destinée au dépôt et à la diffusion de documents scientifiques de niveau recherche, publiés ou non, émanant des établissements d'enseignement et de recherche français ou étrangers, des laboratoires publics ou privés. 


\title{
Outline of a methodic realization of construction kits for changeable production systems
}

\author{
Michael Quade ${ }^{1}$, David Jentsch ${ }^{2}$, Egon Mueller ${ }^{2}$ \\ ${ }^{1}$ Siemens AG Corporate Technology, Munich, Germany \\ michael.quadedsiemens.com \\ ${ }^{2}$ Chemnitz University of Technology, Department of Factory Planning and Factory Manage- \\ ment, Chemnitz, Germany \\ \{david.jentsch, egon.mueller\}@mb.tu-chemnitz.de
}

\begin{abstract}
This paper outlines a method to structure a construction kit system for assembly and manufacturing systems in a way, that a realised system from those building blocks fulfils the requirement of ease in reconfiguration considering specified change criteria (i.e. variants, capacity) at an adequate degree. An overview regarding the major engineering domains and applicable literature is given. The basic flow in this method is given and important steps described. This paper finishes with describing further steps for finalizing the method.
\end{abstract}

Keywords: Production equipment, reconfigurability, flexibility, change enablers, construction kit

\section{Introduction}

Due to increased market competition, globalisation combined with changes in customers' requirements towards higher product variance and uncertain market prediction increase the pressure for changeability of production environments. This topic is discussed on different levels of factory and production system since years (e.g. [1], [2].

Nevertheless, on various levels sufficient changeability from industries perspective is yet not achieved. Uncertainties regarding the change criteria as well as the unspecific implementation of changing enabling measures often negate the positive impact of changeability. This results in increase in systems cost hindering dissemination of the changeability paradigms.

This paper outlines an approach for a methodical design process for construction kit systems. A construction kit establishes building blocks (or modules) suitable to set-up a large (sometimes infinite) number of final products by combining these elements. Assembly and manufacturing systems consisting of building blocks structured by the method fulfil requirements for flexibility and reconfiguration regarding defined change criteria. This is intended to provide systems with a fit of cost and changeability.

adfa, p. 1, 2011.

(C) Springer-Verlag Berlin Heidelberg 2011 
Realizing changeability on production system level is subject of a variety of publication (e.g. [3]-[5]). Its huge complexity combined with its impact on productivity makes this level highly attractive for investigation. Various system suppliers developed modular assembly systems, which are accepted by industry and provide limited changeability by rather fixed solutions. Nevertheless, applicable methods to guarantee deliberately designed changeability by considering the requirements for changeability in the design process of the construction kit system for realized machinery are yet not available to industry.

In this initial publication, the fundamental flow when using the methodic approach from the perspective of production equipment manufacturers is given. Future work will further elaborate on details.

\section{Overall goal}

The approach for setting-up equipment with a construction kit designed by the presented methodology is depicted in Fig. 1:

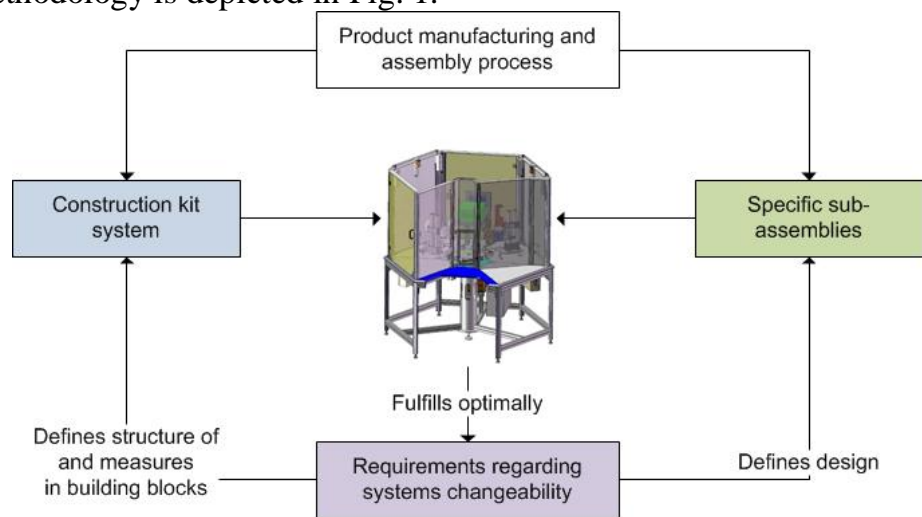

Fig. 1. Setting-up of changeable, kit-based production equipment

Optimally, for a new production process a system consists of building blocks from the construction kit, enriched by specific sub-assemblies. This allows setting up the system quickly and efficiently, while addressing special production processes accordingly. On the one hand, requirements for changeability (e.g. change criteria) define the design of specific sub-assemblies. On the other hand, they also lead to adequate structuring of the construction kit and defining measures in the blocks. Whereas in some blocks measures for e.g. high mobility are required, others may require a different set of enabling measures depending on their functionality.

Implementing a change enabler in a particular building block is beneficial only in case that it is relevant for the criteria in conjunction with the function realized in the building block. Which measures need to be implemented in a specific building block depends on two facts:

1. The dependencies of the functions realized by the building block on relevant change criteria 
2. The dependencies of the change enabler on the relevant change criteria

\section{Review of relevant engineering domains}

In this section, an overview shall be given regarding the relevant engineering domains being part of the presented approach.

\subsection{Domain Design Methodologies}

Different methodologies for product design had been established in the past years: besides traditional product development processes [6], [7], special processes for modular structures and construction kits emerged [8]-[10]. Generally, those processes include a functional analysis, being the basic step in defining the product. Components, modules or in the case of construction kits building blocks are allocated to one or several functions being its function carrier. This combination of the functional and physical description is the product architecture.

As construction kits are explicitly relevant in the approach presented in this publication, this specialisation of product design will be presented in more detail. A thorough overview including advantages, risks and opportunities is presented in [7], [11].

Combining building blocks according to requested functions for a product allows fulfilling many different customers' requirements cost efficiently with a limited amount of block entities. Building blocks may exist in different variations, increasing the amount of final products even further.

The nature of the analysed functions map to the building blocks accordingly: distinguishing mandatory, eventually mandatory and optional functions structures the building blocks analogously.

Due to the compatibility of their building blocks, construction kits allow adapting the product and its functionality easily during the usage phase of the product.

\subsection{Domain Production Systems}

Basically, the term production includes all aspects for transforming raw material into final products. Auxiliary material as well as energy could be required for this transformation, which will take place on production equipment. Relevant publications considering production systems (the actual utilization of the construction kit) include [12], [13].

Two major areas being part of a production system include manufacturing and assembly systems. Manufacturing as defined in [14] includes all processes changing the material composition or spatial relationships of products. Although joining processes are part of this definition, assembly as defined in [15] is often examined separately.

A functional analysis of systems in assembly and manufacturing may indicate large similarities; nevertheless, the detail requirements differ tremendously (e.g. in the case of mechanical requirements on manufacturing systems to prevent vibration). These 
differences clearly influence the design of adequate building blocks and their relationships. For the method presented below, both production areas are considered.

Another fundamental aspect for the method presented is the production level, which is object of matter. According to [16], those levels range from a distributed factory network level, via site, segment, system, cell to a single station, realizing one particular process. As the presented method reflects on the realization of production equipment from building blocks, the relevant level is on cell and system level.

\subsection{Domain Changeability}

In a variety of publications, the concepts of change processes are subject of matter [4], [17]-[20]. Although differences exist in the details, many aspects are identical:

- Change drivers, such as demand volatility and company strategy, trigger the need for a change process

- Change criteria, such as product variant or volume (which often are defined vaguely), are the objective of the change process

- Change enablers, such as mobility or compatibility (whose relevant measures according to a given change object are often vague), allow a system to be changed easily according to the change criteria

Some authors employ the hierarchical view on production systems (levels as presented above) in order to discern different kinds of change. A frequently cited source [21] draws attention to different modes of adaption: flexibility and reconfiguration. The difference of either of these modes is depicted in Fig. 2.

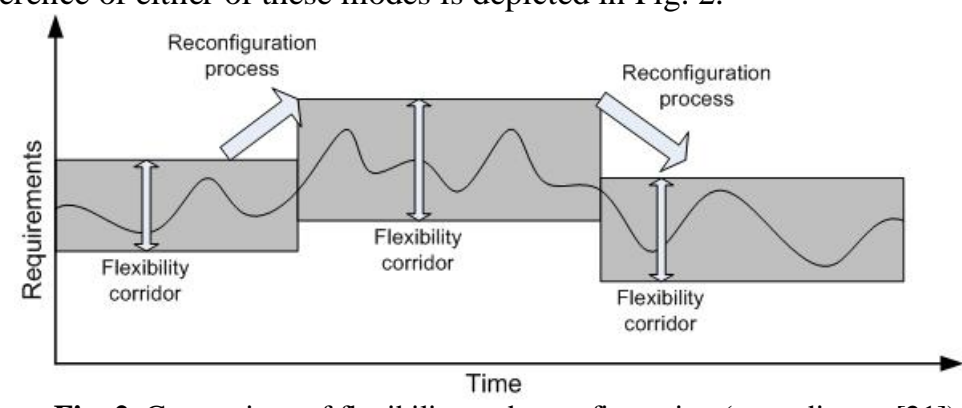

Fig. 2. Comparison of flexibility and reconfiguration (according to [21])

Following this logic, the definition is as follows:

- Flexibility: Ability of a system to economically adapt to changes of requirements in a given corridor

- Reconfigurability: Ability of a system to easily change the flexibility corridor 


\section{$4 \quad$ Outline of basic approach}

The three major domains briefly reviewed above will be combined to describe a methodic approach for realizing a construction kit for assembly and manufacturing systems, which fulfills the requirements for changeability in an optimal fashion. The basic idea is depicted in Fig. 3:

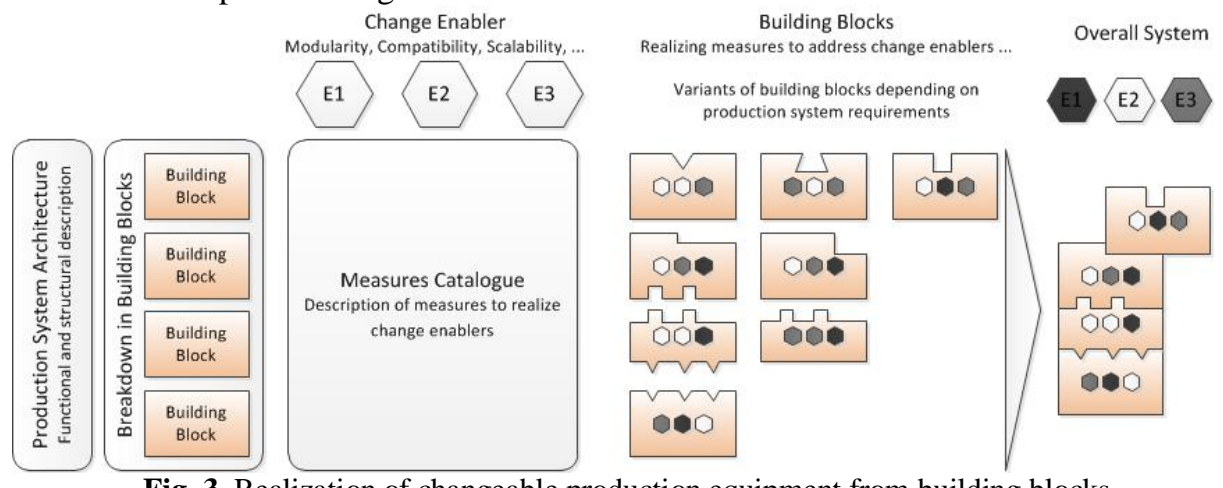

Fig. 3. Realization of changeable production equipment from building blocks

It needs to be highlighted, that detailing the methodic approach divides in two parts:

1. Required analysis for developing the method

2. Required analysis when using the method

The content of this publication focuses on the second part, i.e. using the method from the perspective of a machine supplier or end user (e.g. production management). At this stage, only a general overview will be given. Simplified, the method consists of the following steps:

1. Assessing relevant change criteria

2. Defining change enablers in building blocks

3. Realizing change enabling measures in building blocks

\subsection{Assessing relevant change criteria}

As described above, relevant change criteria to consider in assembly or manufacturing systems realized by building blocks need to be captured. This is a tremendously important step, as only structuring a kit which addresses valid change criteria will lead to a system useful during its usage period.

If optimal reconfiguration of a system addresses an unnecessary change criteria, instead of increasing efficiency the opposite effect will occur (more expensive systems and change processes). ${ }^{1}$

\footnotetext{
${ }^{1}$ In further development of the method itself, weighting of change criteria against each other could be implemented, allowing emphasizing one relevant criterion over another one.
} 


\subsection{Defining change enablers in building block}

Based on the previous step of the method, identification of change enablers to be realized in certain building blocks is required. It is inefficient to realize the whole set of change enablers in each building block. Instead, enablers to implement in a specific building block are defined by evaluating the functions, which are fulfilled by the building block.

As outlined above, two facts need to be taken into account:

- The dependencies of the functions realized by the building block on relevant change criteria

- The dependencies of the change enabler on the relevant change criteria ${ }^{2}$

Exemplarily, a function Move and orientate product (intra-system handling) is heavily impacted by the change criteria product variant. Additionally, regarding handling functions, the enabler universality strongly relates with the criteria. Thus, the building block realizing the function shall include measure to implement universality ${ }^{3}$.

\subsection{Realising change enabling measures in building blocks}

As in the previous step a set of change enablers were defined for each building block, finally measures to be implemented during the design of the construction kit system will be chosen. This can be done in conjunction with the set of functions realized by the building block, and a measures catalogue is envisaged to guide designers during developing the kit.

To fulfill the enablers in the designated kit modules appropriately, this catalogue includes

- Specific design elements for building block (e.g. wheels to address mobility)

- Non-functional requirements for the building block (e.g. minimal weight of building block to address mobility)

- Solution component for function (e.g. jointed-arm robot for pick and place process to address universality)

- Description of interfaces between building blocks and environment (to address compatibility)

Implementing change enablers in building blocks at different extend may be relevant, allowing realizing a manufacturing or assembly system optimally according to the specific requirements of the application case. Although some generic catalogue en-

\footnotetext{
${ }^{2}$ Defining the relationship between change criteria and enablers depending on the system functions is amongst the major developments to be conducted in the future.

${ }^{3}$ In case that weighting the change criteria will take place, clearly different change enablers in building blocks are rated, too. In case of contradicting enabling measures in one building block, this allows guidance in the design process.
} 
tries will be given, its content largely depends on the domain, in which the system suppliers or end users business takes place.

\section{$5 \quad$ Conclusion and outlook}

In this paper an overview was given regarding the development of a method to support the developing of a construction kit system. A construction kit realized by this methodic approach, allows setting up manufacturing and assembly systems, which address crucial change criteria in an optimal, cost efficient way. This will strengthen the dissemination of changeable systems in industrial application.

Although the basic steps of the method had been defined, further work is required: Decomposing the functions of manufacturing and assembly systems is the first crucial step in construction kit design. One major difference to other products is the high degree of uncertainty on the requirements of a realised system. Major reason for this lies in an unknown assembly and manufacturing process and the characteristics of the processed parts. Generally, when structuring the kit, these products are unknown and only general constrains could be assumed.

A catalogue for implementing specific measures according to defined change enablers need to be defined. This includes the structure of the catalogue as well as the initial content. It is envisaged to perform an analysis of available catalogues presented in a number of publications.

The relationship between crucial change criteria and relevant change enablers and measures for certain function carriers needs investigation. The linkage currently is rather vague and based on expert knowledge of industrial and equipment engineers. A more structured approach is required to formalize this aspect.

\section{References}

[1] H.-P. Wiendahl, P. Nyhuis, M. F. Zäh, H.-H. Wiendahl, N. Duffie, and M. Brieke, "Changeable Manufacturing - Classification, Design and Operation," CIRP Ann. - Manuf. Technol., Jan. 2007.

[2] H. A. ElMaraghy and H.-P. Wiendahl, "Changeability - An Introduction," in Changeable and Reconfigurable Manufacturing Systems, 2009.

[3] Y. Koren, "The rapid responsiveness of RMS," Int. J. Prod. Res., Nov. 2013.

[4] J. Pachow-Frauenhofer, "Planung veränderungsfähiger Montagesysteme," 2012.

[5] J. Ackermann, F. Börner, H. Hopf, S. Horbach, and E. Müller, "Approaches for planning and operation of adaptable factories," Int. J. Prod. Res., 2013. 
[6] K.-H. Grote, F. Engelmann, W. Beitz, M. Syrbe, and J. Beyerer, "Entwicklung und Konstruktion," in Hütte das Ingenieurwissen, Berlin, Heidelberg, 2012.

[7] K. Ehrlenspiel, A. Kiewert, and U. Lindemann, Kostengünstig Entwickeln und Konstruieren. Berlin, Heidelberg: Springer Berlin Heidelberg, 2007.

[8] R. B. Stone, "Towards a Theory of Modular Design,” 1997.

[9] I. M. Baumgart, "Modularisierung von Produkten im Anlagenbau," 2005.

[10] J. Göpfert, “Modulare Produktentwicklung,” 1998.

[11] G. Pahl, W. Beitz, and J. Feldhusen, Konstruktionslehre. 2006.

[12] M. Schenk, S. Wirth, and E. Müller, Fabrikplanung und Fabrikbetrieb. 2014.

[13] G. Spur, "Produktion," in Hütte das Ingenieurwissen, 2008.

[14] DIN, DIN 8580: Einteilung der Fertigungsverfahren. 2003.

[15] DIN, DIN 8593: Fertigungsverfahren Fügen, no. 0005. 2003.

[16] H.-P. Wiendahl, "Wandlungsfähigkeit, Schlüsselbegriff der zukunftsfähigen Fabrik," vol. 92, no. 0, pp. 122-127, 2002.

[17] H. A. ElMaraghy, "Flexible and reconfigurable manufacturing systems paradigms," Int. J. Flex. Manuf. Syst., Oct. 2006.

[18] R. G. Landers, J. Ruan, and F. Liou, "Reconfigurable Manufacturing Equipment," in Reconfigurable Manufacturing Systems and Transformable Factories, 2006.

[19] G. Pritschow, C. Kircher, M. Kremer, and M. Seyfarth, "Control Systems for RMS and Methods of their Reconfiguration," in Reconfigurable Manufacturing Systems and Transformable Factories, 2006.

[20] P. Nyhuis, Wandlungsfähige Produktionssysteme. 2008.

[21] M. F. Zäh, N. Möller, and W. Vogl, "Symbiosis of Changeable and Virtual Production," in International Conference on Changeable, Agile, Reconfigurable and Virtual Production, 2005. 